\title{
RANCANGAN SISTEM INFORMASI PENJUALAN BERBASIS WEB PADA LOOKASS LOOKISS ART WORK GARAGE GUNA MEMPERLUAS AREA PENJUALAN
}

\author{
Dani Anggoro ${ }^{1 *}$, Rayyan Budiman' ${ }^{2}$, Rhesa Ariesco Febrian ${ }^{3}$, Yandika Gema Kumara ${ }^{4}$ \\ ${ }^{1}$ Fakultas Teknologi Informasi, Sistem Informasi, Universitas Budi Luhur, Jakarta, Indonesia

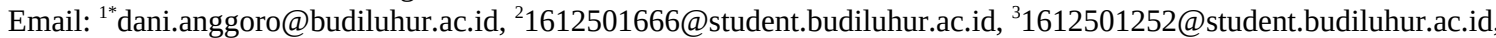

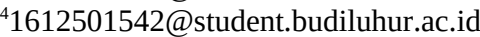 \\ (* : coressponding author)
}

\begin{abstract}
Abstrak-Lookass Lookiss Art Work Garage merupakan usaha yang bergerak di bidang penjualan produk seni, salah satu produknya adalah desain seni mural. Seni mural adalah bentuk seni dua dimensi yang ditampilkan pada ruang publik. Seni ini sering dijumpai di tembok-tembok rumah pinggir jalan, tembok gang maupun sarana umum lainnya. Seni mural saat ini mulai berkembang karena dapat merubah kesan ruangan atau bangunan menjadi bernilai seni dan menarik perhatian masyarakat umum. Kesempatan tersebut dimanfaatkan oleh pengusaha yang bergerak di bidang seni untuk mulai menjual jasa desain seni mural dalam bentuk digital. Masalah utama yang dihadapi dalam penjualan ini adalah pencatatan data pemesanan yang tidak terorganisir dengan baik serta terbatasnya area penjualan jasa seni mural. Dengan permasalahan tersebut maka akan dibangun sebuah aplikasi penjualan berbasis website yang dapat diakses pelanggan tanpa terbatas waktu dan tempat. Metode yang digunakan dalam penelitian ini adalah prototype dengan tahapan analisis, perancangan sistem, pembuatan prototype dan pengujian. Metode pengumpulan data dilakukan dengan observasi di lokasi riset, wawancara dengan pemilik usaha mapun pelanggan dan studi literatur buku maupun jurnal. Sistem informasi yang dibangun terdiri dari pemesanan, pembayaran serta pengiriman desain. Diharapkan dengan sistem ini dapat mempermudah pelanggan dalam memesan desain seni mural serta dapat meningkatkan jangkauan area penjualan bagi pemilik usaha.
\end{abstract}

Kata Kunci: sistem informasi, penjualan, mural, area penjualan, website

Abstract-Lookass Lookiss Art Work Garage is a business that is engaged in the sale of art products, one of the products is mural art design. Mural art is a beautiful two-dimensional art form in public spaces. This art is often found on the walls of roadside houses, alley walls and other public facilities. Mural art is currently starting to develop because it can change the impression of a room or building into artistic value and attract the attention of the general public. This opportunity was used by entrepreneurs engaged in the arts to start selling mural art design services in digital form. The main problem related to this sale is the poorly organized recording of ordering data and the limited sales of mural art services. With these problems, a website-based sales application will be built that can be accessed by customers without limited time and place. The method used in this research is a prototype with the stages of analysis, system design, prototyping and testing. Methods of data testing are carried out by observation at the research location, interviews with business owners and customers and literature studies of books or journals. Information system built from ordering, payment and delivery of designs. It is hoped that this system can make it easier for customers to order mural designs and can increase the reach of the sales area for business owners.

Keywords: information systems, sales, murals, sales areas, websites

\section{PENDAHULUAN}

Fenomena beriklan atau menyampaikan pesan kepada masyarakat melalui seni mural telah banyak dilakukan di kota-kota besar. Selain sebagai media menyampaikan informasi, penempatan seni mural yang tepat dapat mengubah wajah bangunan yang terlihat tidak terawat maupun kumuh menjadi bernilai seni dan menarik perhatian masyarakat umum. Mural merupakan lukisan yang dibuat secara langsung atau tidak langsung pada permukaan dinding bangunan. Coretan-coretan mural pada dinding menggunakan komposisi warna, garis, bentuk dan volume untuk menuliskan kata, simbol, atau kalimat tertentu [1]. Menurut [2] penggunaan warna di suatu ruangan mampu meningkatkan minat seseorang tersebut terhadap suatu obyek.

Melihat peluang yang ada, pemilik usaha seni rupa berusaha untuk mengembangkan usaha dengan menjual jasa desain seni mural dalam bentuk digital yang selanjutnya dapat diimplementasikan pada objek yang diinginkan. Ditengah proses penjualan desain sering terjadi masalah seperti hilangnya data pemesanan atau salah melakukan kalkulasi harga. Metode penjualan dirasa kurang efektif karena tidak dapat menjangkau daerah yang jauh dari lokasi usaha. masalah tersebut disebabkan karena pemilik usaha masih menerapkan sistem yang manual seperti pencatatan pemesanan melalui media kertas, pembeli harus datang langsung ke tempat usaha untuk melakukan pemesanan dan tidak ada pembuatan laporan hasil yang dapat dilihat secara cepat dan akurat. 
available online at http://jom.fti.budiluhur.ac.id/index.php/IDEALIS/index

Ditengah perkembangan teknologi yang cepat saat ini, penggunaan sistem informasi berbasis web sudah semestinya diimplementasikan dalam menjalankan usaha terutama untuk menjangkau pelanggan yang jauh dari lokasi usaha. Dengan menjangkau pelanggan lebih luas tentu akan meningkatkan omset bagi pemilik usaha. Menurut [3] website berjenis $e$-commerce adalah sebuah ranah bisnis yang baru berkembang pesat di Indonesia. Sistem informasi merupakan cara yang teroganisir dalam mengumpulkan, memasukan, mengelola dan melaporkan informasi sehingga mencapai tujuan yang ditentukan [4]

Beberapa peneliti sebelumnya telah melakukan penelitian terkait dengan sistem informasi penjualan diantaranya Menerut penelitian dari [5] yang berjudul analisis dan Perancangan Sistem Informasi Penjualan Online untuk Meningkatkan Pemasaran produk UMKM Kerajinan Tas. Permasalahan yang sering dihadapi pada UMKM Kerajinan Tas adalah proses pemasaran dan promosi produk kerajinan tang saai ini masih dilakukan secara manual dan terbatas hanya dari mulut ke mulut sehingga pemasaran yang didaerah tertentu saja. Hasil dari penelitian ini adalah sistem penjualan online dapat membantu proses pemasaran produk kerajinan tas dengan memproses pemesanan produk yang dilakukan oleh member. Sedangkan menurut penelitian dari [6] yang berjudul Sistem Informasi Penjualan Sepatu Berbasis Web Pada Toko Stephen Sports, permasalahan yang terjadi adalah ada beberapa media yang menyinggung efisiensi waktu dalam hal pemesanan barang Hasil dari penelitian ini adalah Sistem Informasi Penjualan Sepatu Berbasis Web. Sedangkan menurut penelitian dari [7] yang berjudul Sistem Informasi Penjualan Barang Berbasis Website Pada Toko Kmart Koperasi Pekerja Nok Indonesia, permasalahan yang terjadi adalah kurang efisen karena adanya antrian kasir. Hasil dari penelitian ini adalah sebuah sistem informasi yang dapat mempermudah proses jual beli, cek stok barang, dan pembayaran yang semula harus mengantri di kasir menjadi metode konfirmasi pembayaran. Dan menurut penelitian [8] yang berjudul Sistem Informasi Penjualan Barang Berbasis Ecommerce Pada CV. Citra Bersama Banda Aceh, masalah yang terjadi adalah pembuatan laporan membutuhkan waktu yang relatif lama. hasil dari penelitian ini adalah Sistem informasi penjualan berbasis website yang dapat mengasilkan laporan lebih cepat mempermudah pelanggan melakukan pemesanan pelayanan jasa dan produk percetakan secara efektif dan efisien. Berdasarkan uraian diatas dibuatlah rancangan sistem informasi penjualan berbasis web pada Lookass Lookiss Art Work Garage untuk meningkatkan jangkauan area penjualan sekaligus mempermudah pelanggan dalam melakukan pemesanan jasa.

\section{METODE PENELITIAN}

Metode yang digunakan dalam membuat rancangan sistem informasi penjualan berbasis web ini adalah prototype. Prototype bukanlah sesuatu yang lengkap, tetapi sesuatu yang harus dievaluasi dan dimodifikasi kembali. Dengan menggunakan metode ini peneliti dan pengguna sistem dapat berinteraksi selama pembuatan sistem. Dalam membangun sistem ini dibutuhkan proses pengumpulan data, perancangan dan evaluasi. Prototype adalah salah satu metode pengembangan perangkat lunak yang banyak digunakan. Dengan menggunakan metode prototyping, pengembangan dan pelanggan dapat saling berinteraksi selama proses pembuatan sistem [9]. Langkah-langkah penelitian ditunjukkan pada Gambar 1.

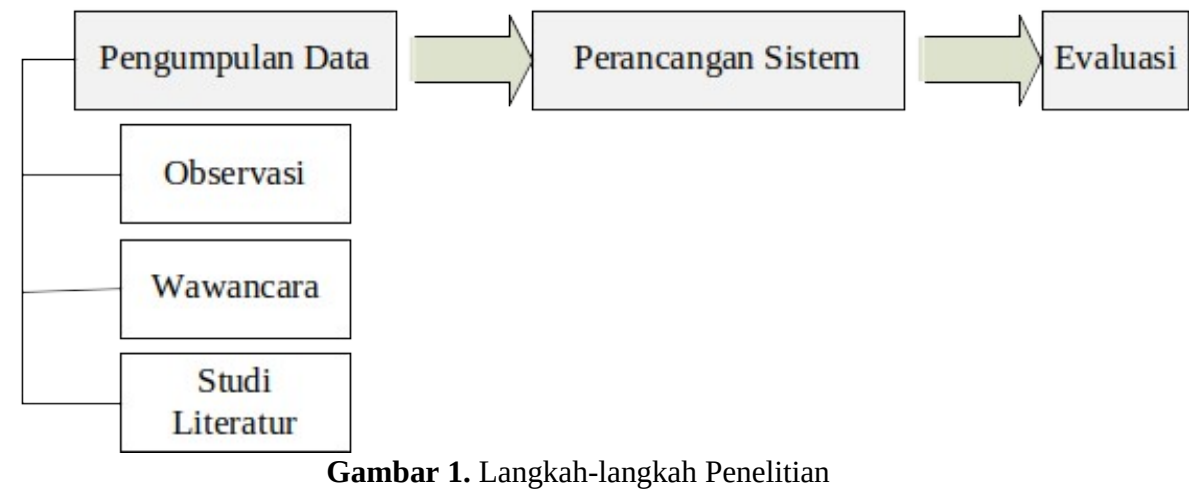

Dalam proses pengumpulan data dilakukan dengan observasi atau pengamatan langsung kegiatan yang berjalan di tempat riset. Wawancara dilakukan dengan bertanya langsung kepada pemilik usaha dan beberapa pelanggan yang sedang melakukan pemesanan. Sedangan studi literatur dilakukan untuk memperoleh data teoritis yang bersumber dari jurnal ilmiah dan buku yang berkaitan dengan sistem informasi penjualan berbasis website. Sumber tersebut dijadikan sebagai pendukung teori dari penelitian yang dilakukan.

Proses perancangan sistem dilakukan dengan menganalisis data yang sudah diperoleh dari observasi, wawancara, maupun studi literatur. Hasil dari analisis diimplemntasikan dalam bentuk diagram-diagram UML 
available online at http://jom.fti.budiluhur.ac.id/index.php/IDEALIS/index

seperti use case diagram untuk menggambarkan interaksi pengguna dengan sistem, class diagram untuk menampilkan rancangan struktur database yang akan digunakan dalam sistem informasi penjualan berbasis web dan tampilan layar yang menggambarkan bentuk tampilan yang dihadapkan ke pengguna

Evaluasi dilakukan untuk mengetahui sejauh mana keberhasilan sistem informasi yang dibuat. Metode yang digunakan untuk mengevaluasi hasil rancang bangun sistem informasi penjualan berbasis web adalah Black-Box testing. Black-Box testing merupakan pengujian perangkat lunak yang merupakan tes fungsionalitas dari aplikasi yang tidak mengacu pada struktur internal atau tidak membutuhkan pengetahuan khusus pada kode program aplikasi dan pengetahuan pengguna. [10]

\section{HASIL DAN PEMBAHASAN}

\subsection{Proses Bisnis Usulan}

Pada proses bisnis usulan yang diusulkan kepada Lookass Lookiss Art Work Garage sebagai berikut :

a. Proses Bisnis Pemesanan

Pelanggan dapat melakukan pemesanan dengan mengunjungi website Lookass Lookiss Art Work Garage. pelanggan memilih menu pesan, jika pelanggan belum pernah melakukan pemesanan sebelumnya, pelanggan diminta untuk melakukan pendaftaran dengan mengisi beberapa data seperti user, email dan no handphone. Selanjutnya pelanggan akan menerima email yang berisi informasi untuk login. Pelanggan yang sudah memiliki informasi login dapat melakukan login dengan memasukan user dan password. Selanjutnya pelanggan memilih jenis barang atau jasa. Setelah pemesanan selesai pelanggan akan dihubungi oleh admin melalui aplikasi chat WhatsApp untuk detail barang atau jasa yang dipilih, jika desain sudah sesuai dengan keinginan pelanggan, admin akan mengirimkan tagihan pembayaran melalui email.

b. Proses Bisnis Pembayaran

Pelanggan yang telah selesai melakukan pemesanan akan menerima email tagihan, selanjutnya pelanggan melakukan pembayaran melalui tranfer bank, jika sudah melakukan pembayaran, pelanggan diminta untuk melakukan konfirmasi pembayaran melalui website Lookass Lookiss Art Work Garage. Setelah selesai konfirmasi pelanggan akan dikirimkan rancangan desain dalam bentuk digital ke email pelanggan.

\subsection{Aturan Bisnis}

Adapun aturan bisnis yang diterapkan pada Lookass Lookiss Art Work Garage mengenai seluruh kegiatan bisnis yang berlangsung adalah sebagai berikut:

a. Pelanggan melakukan pemesanan dan konfirmasi pembayaran melalui website

b. Pelanggan melakukan pembayaran melalui transfer bank

c. Pelanggan dapat melakukan komplai perbaikan desain

d. Pelanggan menerima desain dalam bentuk digital dan dikirm melalui email

\subsection{Identifikasi Kebutuhan}

Tahapan selanjutnya adalah mengindentifikasi kebutuhan sistem dengan menggunakan use case diagram. Use Case Diagram ditunjukkan pada Gambar 2. Gambar tersebut menjelaskan kebutuhan sistem untuk penginputan data transaksi. Aktor yang terlibat adalah pelanggan, admin serta sistem

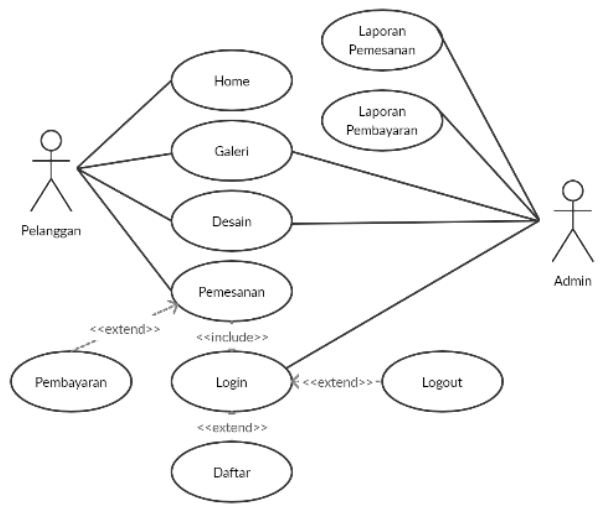

Gambar 2. Use Case Diagram 


\subsection{Rancangan Basis Data}

Rancangan basis data yang digunakan dalam membangun sistem informasi penjualan berbasis web pada Lookass Lookiss Art Work Garage ditampilkan dalam bentuk Class Diagram yang ditunjukkan pada Gambar 3

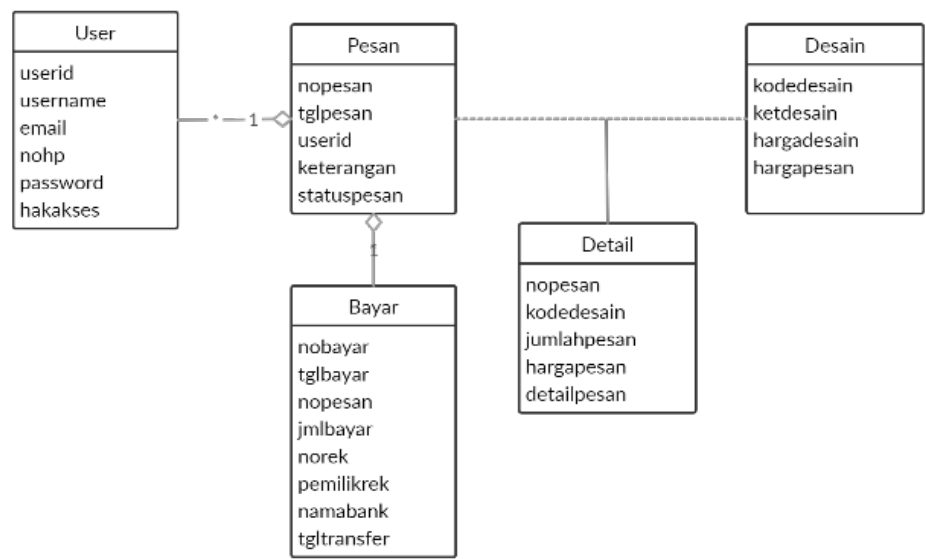

Gambar 3. Class Diagram

\subsection{Struktur Menu}

Struktur menu tampilan dari sisi pelanggan terdiri dari Home, Galeri Desain, Pemesanan dan Konfirmasi Pembayaran. Gambar Struktur menu dari tampilan sisi pelanggan ditunjukkan pada Gambar 4.

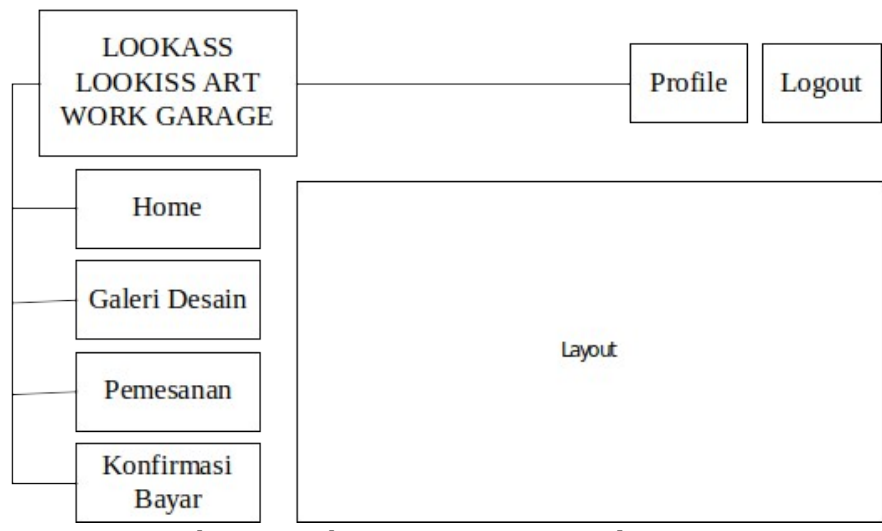

Gambar 4. Struktur Menu Dari Sisi Pelanggan

\subsection{Tampilan Layar}

Tahapan selanjutnya yaitu membuat tampilan layar.

\subsubsection{Tampilan Layar Login Pelanggan}

Pelanggan yang sudah mendaftar melakukan login melalui form login seperti yang ditunjukkan pada Gambar 5 . 


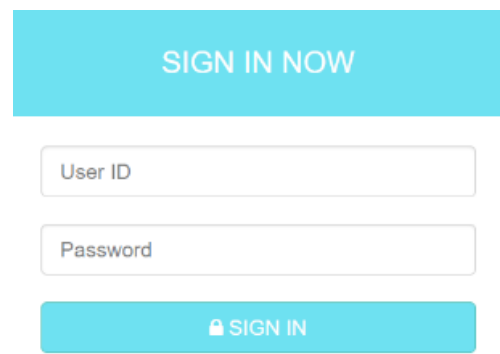

Gambar 5. Tampilan layar Login

\subsubsection{Tampilan Layar Pemesanan}

Untuk memesan barang/jasa desain pelanggan memilih produk, serta jumlah yang ingin dipesan, selanjutnya sistem menampilkan estimasi jumlah yang harus dibayar. Tampilan layar pemesanan ditunjukkan pada Gambar 6.

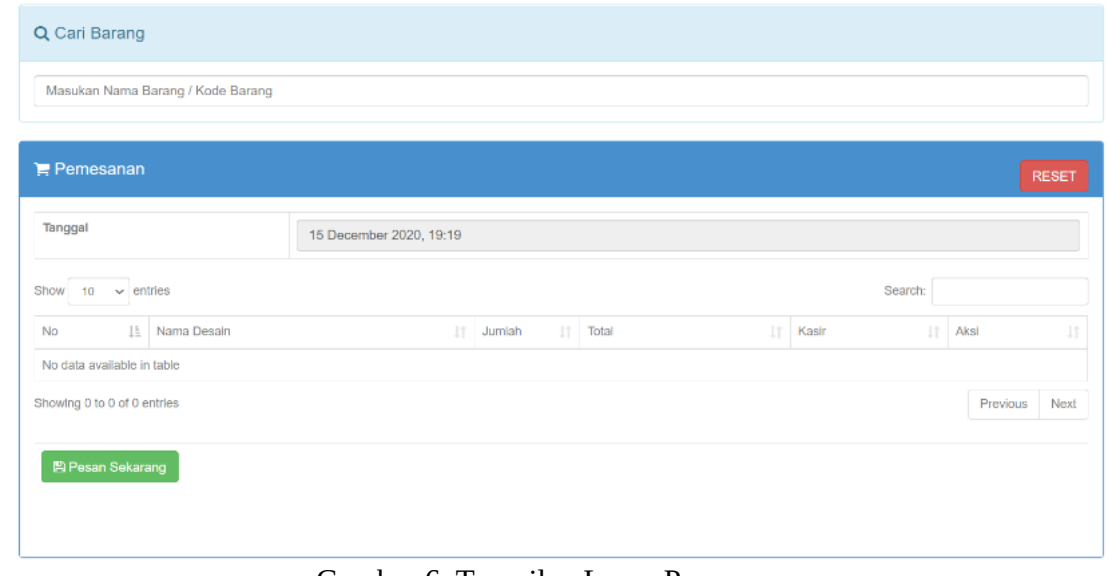

Gambar 6. Tampilan Layar Pemesanan

\subsubsection{Tampilan Layar Konfirmasi Pembayaran}

Untuk konfirmasi pembayaran yang dilakukan pelanggan ditunjukkan pada Gambar 7. pelanggan mengimputkan data pembayaran yang telah dilakukan.

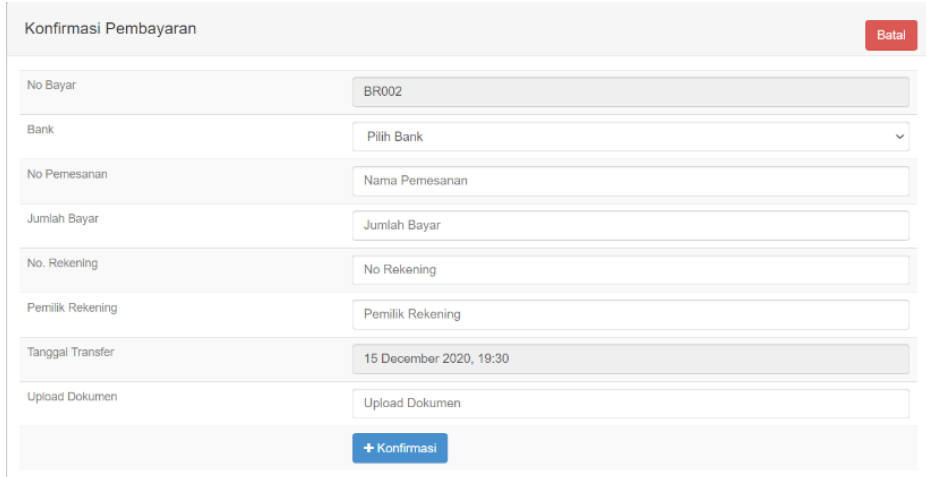

Gambar 7. Tampilan Layar Konfirmasi Pembayaran 
INDONESIA JOURNAL INFORMATION SYSTEM (IDEALIS)

Volume 4, Nomor 1, Januari 2021

ISSN 2684-7280 (online)

Halaman 31-36

available online at http://jom.fti.budiluhur.ac.id/index.php/IDEALIS/index

\subsection{Evaluasi}

Pada penelitian ini evaluasi dilakukan dengan menguji sistem informasi penjualan berbasis website menggunakan black box testing yang bertujuan untuk mengetahui sejauh mana keberhasilan sistem informasi yang dibangun. Pengujian melibatkan pelanggan sebagai pengguna sistem. Form yang diuji yaitu form login, form pemesanan, dan form konfirmasi pembayaran. Hasil pengujian menunjukan keberhasilan sistem informasi yang dibangun sehingga dapat digunakan Lookass Lookiss Art Work Garage dalam bertransaksi khususnya pemesanan dan konfirmasi pembayaran.

Tabel 1. Hasil Pengujian

\begin{tabular}{cccc}
\hline Pengujian & Harapan & Hasil & Kesimpulan \\
\hline $\begin{array}{c}\text { Login menggunakan } \\
\text { informasi login yang di kirim } \\
\text { ke email pelanggan } \\
\text { Entri Pemesanan }\end{array}$ & $\begin{array}{c}\text { Login berhasil dan pelanggan dapat } \\
\text { melakukan pemesanan }\end{array}$ & Login berhasil & Berhasil \\
& $\begin{array}{c}\text { Pelanggan dapat melakukan pesanan } \\
\text { dengan melilih barang yang dipesan dan } \\
\text { Entrimasi biaya dapat ditampilkan }\end{array}$ & $\begin{array}{c}\text { Sistem dapat mengirimkan data } \\
\text { pemesanan ke admin kemudian } \\
\text { menampilkan estimasi biaya }\end{array}$ & Berhasil \\
& Pelanggan dapat melakukan entri \\
pembayaran & $\begin{array}{c}\text { Sistem dapat mengirimkan bukti pesan } \\
\text { kemudian admin dapat melihatnya di } \\
\text { laporan pembayaran }\end{array}$ & Berhasil \\
\hline
\end{tabular}

\section{KESIMPULAN}

Rancangan sistem informasi penjualan berbasis web pada Lookass Lookiss Art Work Garage menggunakan metode observasi, wawancara dan studi literatur untuk pengumpulan data. Metode prototype digunakan untuk membangun sistem. Hasil dari penelitian ini adalah rancangan sistem informasi penjualan dan berbasis web dan evaluasi sistem. Hasil evaluasi menunjukan bahwa sistem informasi dapat digunakan untuk bertransaksi jarak jauh, sehingga Lookass Lookiss Art Work Garage dapat memperluas area penjualannya.

\section{DAFTAR PUSTAKA}

[1] A. Purnomo and B. Basuki, “Variasi Bahasa Mural Di Daerah Istimewa Yogyakarta,” Caraka, vol. 6, no. 1, p. 84, 2019, doi: 10.30738/.v6i1.6593.

[2] T. Assyfah, M. Halimah, and R. Giyartini, "Seni Mural untuk Meningkatkan Minat Membaca di Perpustakaan SD Laboratorium Percontohan UPI Tasikmalaya,” Indones. J. Prim. Educ., vol. 3, no. 1, p. 29, 2019, doi: 10.17509/ijpe.v3i1.17979.

[3] R. P. Sutanto, “Studi Kasus Website Gramedia sebagai Media Online untuk Membeli Buku,” Nirmana, vol. 17, no. 1, p. 37, 2018, doi: 10.9744/nirmana.17.1.37-41.

[4] Krismiaji, Sistem Informasi Akuntansi, 4th ed. Yogyakarta: YKPN, 2015

[5] W. A. Triyanto, "Analisis dan Perancangan Sistem Informasi Penjualan Online untuk Meningkatkan Pemasaran Produk UMKM Kerajinan Tas,” Indones. J. Netw. Secur., vol. 6, no. 3, pp. 63-67, 2017.

[6] Sofyan and Usman, "Sistem Informasi Penjualan Sepatu Berbasis Web Pada Toko Stephen Sports,” J. Perangkat Lunak, vol. 1, no. 1, pp. 11-21, 2019, doi: 10.32520/jupel.v1i1.779.

[7] A. Multajam and M. A. Sutisna, "Sistem Informasi Penjualan Barang Berbasis Website Pada Toko KMART KOPERASI PEKERJA NOK INDONESIA,” vol. 5, no. 1, pp. 1-10, 2020.

[8] M. N. Mthiyane and A. Hugo, "Sistem Informasi Penjualan Barang Berbasis Ecommerce Pada CV. Citra Bersama Banda Aceh,” J. Informatic, Educ. Manag., vol. 3, no. 2252, pp. 58-66, 2019, [Online]. Available: http://www.tjyybjb.ac.cn/CN/article/downloadArticleFile.do?attachType=PDF\&id=9987.

[9] S. Khoiriyah and R. M. Manikam, "analisis dan Perancangan Sistem Perhitungan Insentif Marketing Trade Menggunakan Sistem Remunerasi,” EDUMATIC J. Pendidik. Inform., vol. 3, no. 2, pp. 99-108, 2019, doi: 10.29408/edumatic.v3i2.1691.

[10] W. N. Cholifah, Y. Yulianingsih, and S. M. Sagita, "Pengujian Black Box Testing pada Aplikasi Action \& Strategy Berbasis Android dengan Teknologi Phonegap,” STRING (Satuan Tulisan Ris. dan Inov. Teknol., vol. 3, no. 2, p. 206, 2018, doi: 10.30998/string.v3i2.3048. 